\title{
Prevalence of dental abrasion and its association with toothbrush frequency among patients attending O.P.D. in Government Dental College and Hospital - A cross sectional study
}

Nayantara Sud ${ }^{1}$

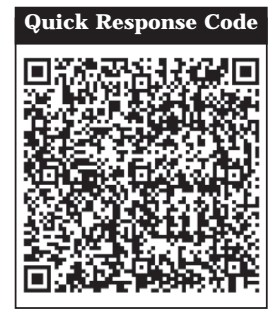

doi: $10.5866 / 2015.7 .10112$

${ }^{1}$ House Surgeon,

H.P. Government Dental College, Shimla.

\section{Article Info:}

Received: April 8, 2015

Review Completed: May 7, 2015

Accepted: J une 6, 2015

Available Online: April, 2015 (www.nacd.in)

(C) NAD, 2015 - All rights reserved

\section{E mail for correspondence:}

shonali3@gmail.com

\begin{abstract}
:
AI M : To assess the prevalence of dental abrasion and its association with tooth brushing frequency among patients attending O.P.D. in H.P.Government Dental College and Hospital, Shimla. Materials and methods: The study was carried out on 100 adults (53 male and 47 female) aged 20 years and above who attended the O.P.D. in H.P.Govenment Dental College and Hospital. The assessment was done using a questionnaire about general information and brushing frequency. The subjects were examined clinically for lesions. Data was analysed SPSS version 15. Statistical test used was chi square test. ' $P$ ' value of $\leq 0.05$ and $\leq 0.01$ was considered as statistically significant and highly significant respectively. Results: A statistically significant relationship between abrasive lesions and gender, age groups as well as tooth brushing frequency was found in this study. Conclusion: The prevalence of toothbrushing abrasions increase with age. Increased tooth brushing frequency results in an increase in the number of tooth abrasions. Therefore dental professionals should make requisite recommendations to their patients.
\end{abstract}

Key words: Dental abrasion, tooth brushing and cervical abrasion

\section{INTRODUCTION}

Tooth wear is quite common problem but most often left untreated. Due to the current substantial decline in dental caries, tooth wear is believed to become more noticeable in future. Increased awareness among people towards orodental health and their interest in keeping their dentition healthy for a longer time can lead to wear. ${ }^{1}$ For planning patient's diagnostic protocol and management strategy, it is important to understand the multifactorial nature of tooth wear and its risk factors. ${ }^{2}$ Cervical tooth wear or tooth abrasion is defined as the loss of tooth substance that occurs in 
the absence of carious mechanisms at the cementoenamel junction of a tooth. ${ }^{3}$

At present, tooth brushing is the most common means of oral prophylaxis at individual level. As the potential benefits of tooth brushing to oral health are so huge, that the adverse effects or damage caused by tooth brushing can be rated as rather small. ${ }^{4}$

Abrasion is defined as the pathological wearing away of dental hard tissue by mechanical forces. ${ }^{5}$ Specific cause of these cervical lesions is unknown. ${ }^{6}$ The most common causative factor for cervical lesions are: that they may be caused by a hard tooth brush, excessive brushing pressure and abrasive toothpaste. ${ }^{7,8}$ Though there is possibility that small scratches on the tooth surface due to brushing will be repaired by the precipitation of minerals by the process of remineralisation.

Tooth brushing is more common in modern era. This method will not only improve the oral hygiene status of the community but al so the damage caused will become more evident in occurrence and severity. ${ }^{9}$ Hence the present study was taken up to know the prevalence of abrasion and to find out its correlation with the frequency of tooth brushing among adult patients attending OPD in the department of Public Health Dentistry, H.P Govt Dental College, Shimla.

\section{Materials and Methods:}

A cross-sectional study, after institutional ethical committee clearance, was conducted among randomly selected 100 adults aged 20 years and above who attended the O.P.D. of the department of public health dentistry, H.P.Govenment Dental College and Hospital. Thestudy was conducted from J une 2014 to August 2014. Only those patients using manual toothbrush for cleaning their teeth and who agreed to participate in the study were considered for the study. Those patients who were not willing to participate in the study were excluded. General information about the subject and his brushing frequency was collected through a interview and entered in questionnaire. This was followed by clinical examination for abrasion on the buccal surface of teeth with a standard dental chair light. Theinstruments used were mouth mirror and probe. Patients were examined by a single dentist. Only those lesions which were clearly identifiable at cement-enamel junction of teeth and which were discoloured, non carious, 'C' or ' $\mathrm{V}$ ' shaped and flatfloored wereall taken as wedge-shaped defects. They were recorded for each patient. The subjects with abrasive lesions were classified according to age, gender, frequency of tooth brushing. The data was analyzed using the software statistical package for social sciences version 15(SPPSS inc. Chicago). Statistical test used was chi square test. $\mathrm{P}$ value $\leq$ 0.05 and $\leq 0.01$ was considered as statistically significant and highly significant respectively.

Results: There were 100 patients who qualified for the study. Out of 100 subjects we had 53 males and 47 females. The overall prevalence of cervical lesions in the present population was $13 \%$. The prevalence of cervical abrasion among the males and females was $16.9 \%$ (9 males) and $8.5 \%$ (4) respectively. The difference in prevalence between males and females was statistically significant $(p=0.029)$.

To determine the relationship between abrasive lesions and age, the subjects were divided into five groups; 20-24, 25-34, 35-44, 45-54, 55 and above. The prevalence of abrasive lesions was lowest in the youngest age group (20-24 yrs) and highest in the older age group (55yrs and above). The difference between the groups was statistically significant (Table 1).

The prevalence of cervical lesions was highest among the subjects who brush their teeth three times or more; out of $27,21(77.8 \%)$ has buccal abrasion, and the difference between the groups was statistically highly significant (Table: 2 ).

\section{Discussion:}

In the present study, the overall prevalence of cervical abrasions was $13 \%$ which is higher than 
Table 1: Distribution of subjects with toothbrush abrasion according to age groups.

\begin{tabular}{|c|c|c|c|c|c|}
\hline \multirow[t]{2}{*}{ Age group } & \multicolumn{2}{|c|}{ Abrasion Present } & \multicolumn{2}{|c|}{ Abrasion Absent } & \multirow{2}{*}{$\begin{array}{c}\text { Total } \\
\mathbf{N}\end{array}$} \\
\hline & $\mathbf{N}$ & $\%$ & $\mathbf{N}$ & $\%$ & \\
\hline $20-24$ & 1 & 1.7 & 10 & 98.3 & 11 \\
\hline $25-34$ & 3 & 6.8 & 41 & 93.2 & 44 \\
\hline $35-44$ & 5 & 17.7 & 27 & 84.3 & 32 \\
\hline $45-54$ & 2 & 33.3 & 4 & 66.6 & 6 \\
\hline $55+$ & 3 & 42.8 & 4 & 57.2 & 7 \\
\hline Total & 13 & 12.62 & 87 & 87 & 100 \\
\hline
\end{tabular}

Chi-Square $=18.72 \quad$ p-value $=0.005$ (Highly Significant)

Table 2: Toothbrush Abrasion according to frequency of tooth brushing

\begin{tabular}{lccccc}
$\begin{array}{l}\text { Frequency of } \\
\text { tooth brushing }\end{array}$ & $\begin{array}{c}\text { Number of } \\
\text { subjects }\end{array}$ & Abrasion Present & \multicolumn{2}{c}{ Abrasion Absent } \\
\cline { 3 - 6 } & 45 & $\mathbf{N}$ & $\%$ & $\mathbf{N}$ & $\%$ \\
\hline Once daily & 47 & 5 & 9 & 41 & 91 \\
\hline Twice daily & 8 & 6 & 75 & 23 & 76.6 \\
\hline Thrice daily & & & & &
\end{tabular}

Chi-Square $=4.138$

p-value $=0.003$ (Highly Significant)

6.1\% as reported by David $\mathrm{K}$ but lower than Vrinda S (68.6\%) and Borcic J (60-70\%). ${ }^{10-12}$ The prevalence was higher in males as compared to females which was also reported by Akqhl HM, David K, Radentz et al and Mehmet OZ et al. ${ }^{13-16}$ This can be explained by the increased muscle mass and muscular strength among males which may lead to higher magnitude of forces among them. ${ }^{17}$

The prevalence of abrasive lesions was lowest in the youngest age group (20-24 yrs) and highest in the older age group (55yrs and above) and the difference was statistically significant. This finding is in line with the findings of Borcic $J .{ }^{12}$ This is explained as with increase in chronicity of tooth brushing and the use of abrasives for cleaning the teeth increases proportionately so is the abrasive lesion. Dueto advances in preventiveand restorative dentistry, elderly people are able to preserve their teeth but at the same time it leads to other problems and one of them is cervical lesions.
Patients who brushed with higher frequency showed increased wear rates than patients brushing once a day which was also shown by the studies conducted by Sangnes G, Litonjua et al and Radentz et al.2,15,16 This may be either because of abrasives present in the tooth paste, or increased duration of brushing or due to faulty brushing. The etiology of cervical abrasion is basically multifactorial and is a combination of several types of wear factors, such as age, diet, gingival recession, periodontal health, dentifrice, speed, and pressure used during brushing and which are interrelated.

As such the etiology of the wedge-shaped lesion is very complicated, as there are wide variations in the clinical characteristics of these lesions. Some lesions are narrowly notched at the cement-enamel junction, and some extend broadly into the cementum region. 


\section{Conclusion:}

From the present study it can be concluded that the prevalence of cervical lesions was $6.1 \%$. The prevalence was higher among males as compared to females. The prevalence of lesions was higher in older age group. Frequency of tooth brushing was significantly associated with the occurrence of cervical lesions. So it is hereby recommended that the population must be educated and guided with appropriate prophylactic measures that are effective for oral cleanliness but still harmless to oral tissues. So we as dentists and our paradental staff be wholeheartedly involved in preventing such lesions by teaching correct tooth brushing techniques. To prevent this problem from becoming worse and become a burden on our society, dental professionals should try to combat the problem from its early stages.

\section{References:}

1. Nguyen C, Ranjitkar S, Kaidonis J A, Townsend GC. A qualitative assessment of non-carious cervical lesions in extracted human teeth. Aust Dent J 2008; 53:46-51.

2. Tomasik M.Analysis of etiological factors involved in noncarious cervical lesions. Ann Acad Med Stetin 2006; 52: 125-136.

3. Aw TC, Lepe X, J ohnson GH, Mand L. Characteristics of noncarious cervical lesions: a clinical investigation. J Am Dent Assoc 2002; 133:725-733.

4. Litonjua LA, Andreana S,Bush PJ ,Tobias TS, Cohen RE.Wedged cervical lesions produced by toothbrushing. Am J Dent 2004; 17:237-240.

5. Daly RW, Bakar ZW, Husein A, I smail MN , Mastura ,I smail BT. The study of toothwear patterns and their associated aetiologies in adults in Kelantan, Malaysia. Arch Orofacial Sci 2010; 5:47-52.
6. Sewerin IB. Complex toothbrush abrasions. Quintessence Int Dental Digest 1994; 5:41-43.

7. Christensen LB,Petersen PE, Krustrup U, Kjoller M. Self reported oral hygiene practices among adults in Denmark. Community Dental Health 2003; 20:229-235.

8. Taiwo J O, Ogunyinka A, Onyeaso CO and Dosumu OO (2005). Tooth wear in the elderly population in South East Local Government Area in I badan, Nigeria. Odontostomatol Trop 2005; 28:9-14.

9. Bergstrom J, Lavstedt S. An epidemiological approach to tooth brushing and dental abrasion. Community Dent Oral Epidemiol 1979; 7:57-64.

10. David K, K Mahalinga Bhat. Prevalence Of Tooth Wear In Patients Attending The Department Of Periodontics, Manipal College Of Dental Sciences, Manipal. NJ IRM 2012; 3:136-142.

11. Vrinda Saxena, Naveen Yadav, Shanti G, Amit V, Poonam Dubey. Linking Of Multifactorial Causation In Abrasion Of Teeth Among Adult Residents Of Bhopal Central India. Indian J ournal of Dental Sciences. 2013; 3:9-12.

12. Borcic J, Anic, Urek MM, Ferreri S. The prevalence of noncarious cervical lesions in permanent dentition. J. Oral Rehabilitation.2004; 31:117-123.

13. Akgul HM, Akgül N, Karaoglanoglu S, Ozdabak N. A survey of the correspondence between abrasions and tooth brushing habits in Erzurum, Turkey.I Dent 2003; 53(6):491-495.

14. J ohansson A et al. An investigation of some factors associated with occlusal tooth wearing a selected high wear sample J Dent Res 1993 101; 407-415.

15. Sangnes G, Gjermo P. Prevalence of oral soft and hard tissue lesions related to mechanical toothcleansing procedures. Community Dent Oral Epidemiol 1976; 4:77-83.

16. Radentz WH,Barnes GP, Cutright DE. A survey of factors possibly associated with cervical abrasion of tooth surfaces. J Periodontol 1976; 47:148-154.

17. Ashley P. Toothbrushing: why, when and How? Dental U pdate 2001; 28:36-40.

\section{Gain quick access to our journal online View our journal at www.nacd.in}

